\title{
Device for conversion of equalizing current at the site of the traction ac network
}

\author{
Abdurauf Safarov ${ }^{1}$, Khurshid Sattarov $^{2,3}$, and Sarvar Jumaboyev ${ }^{1}$ \\ ${ }^{1}$ Tashkent institute of railway engineering, Department of Power Supply of Railways, Adilkhodjayev - 1, Tashkent, 100167, \\ Uzbekistan \\ ${ }^{2}$ Tashkent university of information technologies, Department of Power Supply Systems, A.Timur, 108, Tashkent, 100200, Uzbekistan \\ ${ }^{3}$ Tashkent state technical university, Department of Power Supply, Universitet, 2, Tashkent, 100097, Uzbekistan
}

\begin{abstract}
The article proposes the design of a device for converting the equalizing current using a compensating winding, which meets the requirements for accuracy and reliability on the part of various automated control systems, control and measurement of currents.
\end{abstract}

\section{Introduction}

In connection with the aggravation of the problem of saving fuel and energy resources due to the constant increase in prices for them, the issues of further introduction of modern energy-efficient and energysaving technologies are of particular importance [1].

In particular, one of the main problems in railway transport is the problem of reducing the losses of electric energy in the traction power supply system of electrified Railways, which are the largest consumers of electricity in the industry.

The formation of the indicator "loss of electricity" begins with the energy consumption for traction of trains received by the network (meters of traction substations on the primary side of traction transformer substation) and released to the consumers (counters of the electric rolling stock). Thus actual values of losses of the electric power which size depends on reliability of the account of the electric power consumption are defined. For example, in [2] given the accounting data on the electricity consumption for traction by results of work on the Railways of Russia.

In accordance with these reporting data, the range of changes in the relative unbalance of electricity reception for traction trains by meters of traction substations and consumption by meters of electric rolling stock was $2.1 \ldots 27.9 \%$. The difference between the actual and calculated values of losses of electric energy is caused by unsatisfactory technical and organizational condition of systems of the account of electric energy on traction substations and the electric moving structure.

\section{Statement of a problem}

Determination of structure and actual losses of the electric power, to allocate the factors causing these losses for the purpose of development and the organization of actions for reduction of losses of electric energy in a traction network.

\section{The concept of the problem decision}

An electrified AC railway is an asymmetrical non-linear consumer with an uneven load. It is an extended receiver of electric energy, and its traction substations can't be powered from one point of connection to the external power supply system $[3,4]$.

Traction substations are powered by various nodes of one or more power systems. The voltages at the points of connection of traction substations to power systems are different in modulus and phase, which causes the flow of power flows in the traction power supply system between adjacent substations even in the absence of traction load. Connection of systems of external and traction power supply on power transit is accepted to estimate an equalizing current in a traction network [5].

Equalizing current is the current determined by the parameters and mode of operation of external and traction power supply systems. The traction network between two adjacent traction substations in its electrical essence is a small resistance current line connected in parallel to the power line of the external power supply system at long distances. In accordance with Kirchhoff's first law, part of the load current flowing through the power lines of the external power supply system branches off into the traction network (a system of parallel wires). For the traction network, this is a harmful current that causes additional losses of electrical energy, heating of wires, reducing the capacity of trains in this inter-substation zone. The presence of transit of electrical energy in the traction network complicates the system of accounting of electricity for traction of trains.

On Railways seek to reduce the value of the equalizing current. Therefore, the problem of its determination for the purpose of subsequent minimization is acute [6]. 
Losses of electric energy in the traction network, caused by equalizing currents depend on power supply and partitioning merpttazinol areas and are determined by the nature of the traction load, parameters, elements and modes of operation of power lines.

Under operating conditions, these factors change, and therefore it is important to be able to quickly assess the loss of electrical energy in the traction network for various power supply circuits of the inter-substation zone and choose a power supply scheme to minimize energy losses.

Equalizing currents cause additional losses of electricity in the contact network regardless of whether there are trains on the inter-station zone or not. In the absence of a load on the zone, equalizing currents can flow, causing energy losses in the contact network, which are recorded by the meters of substations, but are not measured by the meters of electric locomotives. Therefore, the more time there are no trains in the zone, the greater will be the difference in the readings of the energy meters of substations and electric locomotives.

To estimate this difference, in addition to the value of the equalizing current, it is necessary to know the dimensions of the train movement. Disadvantages of the mode of operation of the traction power supply system of electrified AC Railways are amplified by the imperfect system of accounting for electric energy at traction substations and electric rolling stock.

A significant drawback in the accounting of electricity for traction trains at traction substations is the lack of accounting for electricity on the feeders of the contact network, which prevents the study of the balance of received and distributed electric energy $[7,8]$.

The lack of control of the balance of received and distributed electricity for the traction of trains occurs for the following reasons:

- the absence of metering devices on the feeders of the contact network does not allow to control the distribution of electricity on the supply arms;

-not defined zone with an increased energy consumption for traction of trains with the aim of developing joint solutions services $\mathrm{E}$ and $\mathrm{T}$ to reduce specific energy consumption for traction of trains substation in these areas.

The electric power accounting on the electric rolling stock of alternating current is carried out now by counters of the electric power spent on traction of trains and returned at regenerative braking. They make it possible to determine the specific cost of electricity for the transportation of goods in operation.

Since cash settlement currently on the counters of electric locomotives do not produce, so today, the energy metering on the electric rolling stock is made by induction and electronic electricity meters with lower accuracy class of energy measurement.

Due to the absence of electric voltage transformers, voltage all meters are powered from winding their own needs at the secondary side of traction transformer locomotive, and the circuit from the primary winding of the traction transformer locomotive. However, there is no proportional relationship between changes in the voltage in the contact network and the voltage on the winding of the transformer's own needs.

Therefore, to estimate the specific energy consumption for traction trains for different $\mathrm{AC}$ locomotives have to take the average transformation coefficients. For example, switching at an angle of $40 \ldots 45^{\circ}$ rectifier electric locomotive caused by a large current load of the engine, and because of voltage losses in the dispersion reactance of the secondary windings of traction transformer voltage drop in the winding their own needs differs from the reduction of voltage on the pantograph of the electric locomotive 10 to $20 \%$ in magnitude and $3 \ldots 4^{\circ}$ in phase [7].

As a result, the error of electricity metering on the electric rolling stock is not less than $10 \%$. These errors of the account of the electric power entail emergence of a certain share of conditional losses in system of traction power supply.

Thus, today there is a need to develop a comprehensive system of scientific, technical and organizational measures in the form of an automated system of control and accounting of electricity (ASCAE), taking into account the above factors. This will identify areas with increased losses of electrical energy, develop measures to reduce them, reduce the total energy consumption in the traction power supply system and improve the technical and economic performance of the traction power supply system. For a complete picture of the electric energy consumption for all elements of the traction power supply system, it is necessary to take into account the electric power consumption on the feeders of the contact network and on the electric rolling stock of the phase $[5,9]$.

In addition to continuous monitoring and accounting of electricity, the introduction of ASCAE in the traction power supply system will allow to assess the status of power supply devices, to conduct current control of electricity losses and quality indicators of the received electricity, as well as to identify irrational electricity consumption.

The creation and implementation of such a system on electric rolling stock will allow:

- to control reliability of the account of electric energy on counters of the electric rolling stock and receiving information after processing of route sheets of drivers;

- to provide technical and organizational improvement of the account of the electric power on the electric moving structure;

- control the consumption of electric power by electric locomotives from neighboring roads.

The main objectives for the implementation of ASCAE on electric rolling stock are:

- development of technical solutions for its implementation and on its basis the organization of current control of electricity consumption by electric locomotives on the traction of trains;

- compliance with the legal provision of technical means of ASCAE, which will be possible with the use of a current measuring Converter both on the $25 \mathrm{kV}$ side and on the $10 \mathrm{kV}$ side of an electric locomotive traction transformer and modern electricity metering devices; 
- implementation by means of technical means of binding of power consumption of the electric rolling stock to the served zone (owing to the fact that the electric locomotive is the mobile unit and moves on a site of the railway).

In this paper, the authors propose a design of the device to convert the surge current to meet the requirements of AMR both at $25 \mathrm{kV}$ and $10 \mathrm{kV}$ traction transformer locomotive.

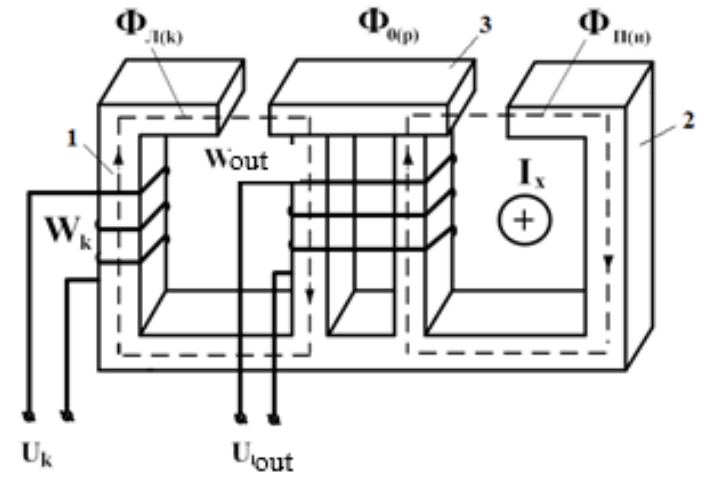

Fig.1.The design of the device to convert the compensating current

The device for converting the equalizing current (Fig.1) is built on the basis of the design [10] for the case of transformation of alternating current and consists of the extreme rods 1 and 2, the magnetic core rod with a cutout 3 , the conductive bus c measured current $I_{x}$, a compensating winding wound $W_{k}$ on the core 1 , an output winding $W_{\text {out }}$, encompassing a Central stem with the neck 3 .

The principle of operation of the Converter is as follows. When the measuring current $I_{x}$ flows through the bus, as well as when the compensating winding $W_{k}$ is connected to an alternating voltage source, a compensating current is formed (Fig. not shown), and in rods 1 and 2 there are magnetic currents proportional to the corresponding currents.

With the same direction of currents in the tires, the magnetic flows $\Phi_{L(k)}$ and $\Phi_{R(i)}$ are closed along the extreme rods 1 and 2 and through the Central rod 3 in opposite directions. The output winding $W_{\text {out }}$ is permeated by magnetic flows $\Phi_{L(k)}$ and $\Phi_{R(i)}$ counter direction. If the bus currents are not equal to each other, then the resulting flow $\Phi_{0(p)}$ is the flow difference, $\Phi_{L(k)}$ and $\Phi_{R(i)}$, and the corresponding voltage at the output of the output winding is determined by the derivative of the flow difference $\Phi_{L(k)}$ and $\Phi_{R(i)}$ in time:

$$
U_{\text {out }}=-W_{\text {out }} \frac{d\left(\Phi_{\mathrm{L}(\mathrm{k})}-\Phi_{\mathrm{R}(\mathrm{i})}\right)}{d t}=-W_{\text {out }} \frac{d \Phi_{0(\mathrm{p})}}{d t}
$$

where is $W_{\text {out }}$ - the number of turns of the output winding.

\section{Conclusion}

Thus, the device for converting the equalizing current using the compensating winding allows you to convert current to AC voltage with high accuracy and reliability, which expands the scope of its application in various automated control systems, control and measurement of currents.

\section{References}

1. O merax po dalneysimu vnedreniyu sovremennix energoeffektivnix I energosberegayushix texnologiy. Postonovlenie Prezidenta Respubliki Uzbekistan ot 23.08.2017g. № PP-3238.

2. Molin N.I. Potentsial energosberejeniya $\mathrm{v}$ sisteme tyagovogo elektrosnabjeniya peremennogo toka jeleznix dorog// Materiali Vserossiyskoy nauchno-texnicheskoy konferensi s mejdunarodnim uchastiem: V 2t. T.1/ Otv. red. V.P. Surov. - Krasnoyarsk: Grotesk, 2005g., s. 3946.

3. Markvardt K.G. Elektrosnabjenie elektrifistirovannix jeleznix dorog. M.: Transport, 1982. $528 \mathrm{~s}$.

4. Tuygunova A.G., Bardushko V.D. Analiz uravnitelnix tokov potyagovim setyam na osnove rschetno-eksperimentalnix dannix ob urovnyax naptyajeniya i ix fazax v uzlax podklyucheniya tyagovix podatantsiy. IrGUPS, Sovremennie texnologii. Sistemniy analiz. Modelirovaniya. №2 (50), 2016.

5. Kashtanov A.S. Povishenie effektivnosti kontrolya elektropotrebleniya i usloviy soglasovaniya system vneshnego i tyagovogo elektrosnabjeniya po dannim ASKUE. Diss. na soisk. kand. tex. nauk, - Omsk, 2007g., s.164.

6. Osipov V.A. Zakonomernosti protekaniya uravniteknix tokov $\mathrm{v}$ elektrotyagovoy seti i metodi ix minimizatsii. Diss. na soisk. kand. tex. nauk, - Rostovna-Donu - 2000g., s.174.

7. Chermisin V.T. Sistema meropriyatiy po snijeniyu poter elektricheskoy energii $\mathrm{v}$ tyagovoy seti ot uravniteknix tokov/ V.T. Chermisin, V.A. Kvashuk// Jeleznodorojniy transport TsNIITEI MPS, - 2000. - Vip. 3., s. 9-21.

8. Cheremisin V.T., Kvashuk V.A. Kontrol uravnitelnix tokov, metodika otsenki poter $\mathrm{V}$ tyagvoy seti peremennogo toka i meropriyatiya po ix snijeniyu//Sb. tr. Vtorogo Mejdunar. sipoziuma ENSB-KE-EMSEME-2000. M.: MIIT, 2000.

9. Chermisin V.T. Texniko-ekonomicheskiy aspect vnedreniya ASKUE na jeleznodorojnom transporte/ V.T. Cheremisin, M.M. Nikiforov, A.L. Kashtanov// Jeleznodorojniy transport. Moskva, 2007, №3, s. 51-53. 10. A.s. №1019503 (SU). Ustroystvo dlya preobrazovaniya postoyannogo toka $\mathrm{V}$ peremenniy/ Zaripov M.F., Axrorov N.A., Safarov A.M., Petrova I.Yu.// Opublikovano "Byulleten izobreteniy"-1983, №19. 